\title{
EFIKASI VARIASI KONSENTRASI PGPR UNTUK MEMACU PERTUMBUHAN BAWANG MERAH (Allium ascalonicum F.) DI BERBAGAI TAKARAN MEDIA KOMPOS
}

\author{
Kafrawi $^{1)}$, Mu'minah ${ }^{1)}$, Nurhalisyah ${ }^{1)}$, Sri Muliani' ${ }^{1)}$, Zahraeni Kumalawati' ${ }^{1)}$ \\ 1) Program Studi Teknologi Produksi Tanaman Hortikultura \\ 2) Program Studi Teknologi Produksi Tanaman Pangan \\ Politeknik Pertanian Negeri Pangkajene Kepulauan \\ Jalan Poros Makassar-Pare km 83, Mandalle Kabupaten Pangkep, Sulawesi Selatan
}

Korespondensi : Kafrawidjamin@gmail.com

\begin{abstract}
ABSTRAK
Tujuan dari percobaan ini adalah mendapatkan data interaksi kosentrasi PGPR dengan takaran pupuk organik yang terbaik dalam memacu pertumbuhan tanaman bawang merah. Penelitian ini menggunakan Rancangan Faktorial dengan dasar Rancangan Acak Kelompok (RAK) dan menggunakan 2 (dua) faktor perlakuan, perlakuan pertama adalah takaran kompos yang terdiri dari 4 level yaitu: tanpa pemberian kompos, tanah + kompos $1: 1$, tanah + kompos $1: 2$ dan tanah + kompos $2: 1$. Perlakuan kedua adalah konsentrasi mikroba PGPR dengan 3 taraf Konsentrasi yaitu 10, 20, dan $30 \mathrm{ml} . \mathrm{L}^{-1}$ air. Terdapat 12 kombinasi perlakuan yang terdiri dari 2 unit penelitian dan diulang kedalam 3 kelompok, sehingga terdapat 72 unit tanaman penelitian. Hasil percobaan menunjukkan bahwa tanaman tertinggi diperoleh dari kombinasi perlakuan media tanah berkompos (1:1) dengan konsentrasi PGPR $30 \mathrm{ml} . \mathrm{L}^{-1}(42,63 \mathrm{~cm})$, jumlah daun per tanaman terbanyak diperoleh dari kombinasi perlakuan media tanah berkompos (2:1) dengan konsentrasi PGPR $10 \mathrm{ml} . \mathrm{L}^{-1}$ (29 helai). Bobot umbi brangkasan segar, bobot umbi brangkasan kering askip, dan bobot umbi protolan kering askip tertinggi semua diperoleh dari kombinasi perlakuan media tanah berkompos (1:1) dengan konsentrasi PGPR $10 \mathrm{ml} . \mathrm{L}^{-1}$ masing-masing sebesar 32,64 g, 19,95 g, dan 11,54 g, sedangkan susut bobot tanaman tertinggi diperoleh dari kombinasi perlakuan media tanah tanpa penambahan kompos dengan konsentrasi PGPR $20 \mathrm{ml}^{-L^{-}}$ ${ }^{1}(18,42 \mathrm{~g})$.
\end{abstract}

Kata kunci: Konsentrasi, PGPR, kompos, bawang merah

\begin{abstract}
The purpose of this experiment was to obtain data on the interaction between PGPR concentrations and the best organic fertilizer rates in spurring onion plant growth. This study used a factorial design based on a randomized block design (RBD) and used 2 (two) treatment factors, the first treatment was a compost dose consisting of 4 levels, namely: without compost, soil + compost 1: 1 , soil + compost 1: 2 and soil + compost $2: 1$. The second treatment was the concentration of PGPR microbes with 3 concentration levels 10, 20, and $30 \mathrm{ml} . \mathrm{L}^{-1}$ water. The 12 treatment combinations were consisting of 2 research units and repeated into 3 groups so that there were 72 research plant units. The experimental results showed that the highest plant was
\end{abstract}


obtained from the combination of composted soil media treatment (1: 1) with a PGPR concentration of $30 \mathrm{ml} . \mathrm{L}^{-1}(42.63 \mathrm{~cm})$, the highest number of leaves per plant was obtained from the combination of composted soil media (2: 1). ) with a concentration of PGPR $10 \mathrm{ml}^{-L^{-1}}$ (29 leaves). The highest of bulbs fresh biomass weight, bulbs dry biomass weight, bulbs fresh biomass shrinkage were all obtained from the combination of composted soil media treatment (1: 1) with a concentration of PGPR $10 \mathrm{ml} . \mathrm{L}^{-1}$ respectively $32.64 \mathrm{~g}, 19.95 \mathrm{~g}$, and $11.54 \mathrm{~g}$, while the highest plant weight loss was obtained from the combination of soil media treatment without the addition of compost with a concentration of PGPR $20 \mathrm{~mL}^{-1}, 42 \mathrm{~g}$ ).

Keywords: Concentration, PGPR, compost, shallots

\section{PENDAHULUAN}

Salah satu komoditi hortikultura yang banyak di budidayakan adalah bawang merah. Saat ini kebutuhan pasar akan bawang merah semakin meningkat tajam, seiring dengan meningkatnya jumlah pelaku bisnis makanan yang tersebar di berbagai daerah. Kondisi ini terjadi karena bawang merah dimanfaatkan masyarakat untuk bahan baku pembuatan bumbu masakan setiap hari, dan menjadi bahan utama dalam proses produksi bawang goreng yang sering digunakan sebagai pelengkap berbagai menu kuliner.

Pertumbuhan luas panen bawang merah jauh lebih tinggi dari pada pertumbuhan produktivitasnya. Hal ini ditunjukkan oleh rata-rata pertumbuhan luas panen bawang merah nasional dalam periode 2014 - 2018 mencapai 10,11\% per tahun, sementara itu produktivitas mengalami penurunan minus $1,23 \%$ per tahun. Namun produksi bawang merah 5 tahun terakhir cenderung meningkat dengan rata -rata pertumbuhan mengalami peningkatan $8,66 \%$ per tahun. Dengan demikian dapat diartikan kemungkinan peningkatan produksi bawang merah lebih dipengaruhi oleh peningkatan luas panen dari pada dipengaruhi produktivitasnya. Oleh karena itu produktivitas bawan merah sebaiknya ditingkatkan (Kementan, 2016)

.Peningkatan permintaan bawang merah seharusnya diimbangi dengan peningkatan produksi bawang merah dalam negeri karena potensi produksi dan lahan di Indonesia memungkinkan untuk itu. Produktivitas rata-rata bawang merah di Sulawesi Selatan, yang hanya 6,0 ton/ha - 9,0 ton/ha, masih sangat rendah bila dibandingkan dari potensi hasilnya 10-20 ton/ha misalnya pada tahun 2011, potensi lahan peruntukan penanaman bawang merah mencapai 93,667 ha sementara produksinya hanya 893,124 ton, ini berarti produktivitasnya hanya 9,54 ton/ha (Suwandi et al., 1995; Badan Pusat Statistik dan Direktorat Jenderal Hortikultura, 2011). 
Perbaikan sistem budidaya sangat penting dilakukan untuk meningkatkan produktivitas lahan sekaligus menekan angka impor bawang merah. Untuk mengurangi volume impor, peningkatan produksi dan mutu hasil bawang merah harus senantiasa ditingkatkan melalui intensifikasi dan ekstensifikasi (Sumarni et al., 2005). Intensifikasi bawang merah dapat ditempuh dengan meningkatkan input produksi berupa pemberian bahan kimia dalam bentuk zat pengatur tumbuh, pupuk dan pestisida.

Input-input bahan kimia senantiasa memerlukan biaya yang cukup mahal dan meninggalkan residu bahan kimia baik pada lahan maupun pada produk pertanian yang dihasilkan sehingga jika dikonsumsi dapat membahayakan kesehatan manusia. Olehnya, pertanian ramah lingkungan beserta produk-produk organiknya menjadi alternatif pilihan konsumen saat ini diantaranya dengan pemanfaatan mikroorganisme berguna untuk tanaman.

Tanah sebagai media tumbuh tanaman banyak mengandung mikroorganisme, beberapa di antaranya cenderung berkoloni disekitar perakaran/rhizosfer tanaman dan beraktivitas menguntungkan bagi pertumbuhan tanaman baik secara langsung maupun tidak langsung dan dapat berkontibusi menggantikan input anorganik. Kelompok mikroorganisme seperti ini disebut plant growth promoting rhizobacteria (PGPR). Menurut Dewi et al. (2007), mikroorganisme menguntungkan ini dapat menjadi komponen yang signifikan dalam manajemen pengelolaan untuk dapat mencapai hasil, yang mana ditegaskan bahwa hasil tanaman budidaya tidak hanya dibatasi oleh lingkungan fisik alamiah tanaman dan potensial genetik bawaan.

Bakteri PGPR didalam tanah akan berkembang biak dengan baik manakala tanah sebagai lingkungan hidupnya sesuai dengan kebutuhannya dalam beraktivitas. Aktivitas metabolisme dan senyawa metabolit yang dilepaskan oleh tanaman ke dalam tanah melalui akar disebut eksudat akar dan aktivitas tersebut merupakan faktor yang sangat menentukan keadaan mikrobiologi tanah pada daerah perakaran tanaman (Gibson, 1981). Eksudat merupakan sumber nutrisi dan dapat berperan sebagai penghambat dan stimulator terhadap populasi rhizobakteria (Lebuhn et al., 1997) dan seringkali menjadi pembeda dan penentu keragaman dan jumlah populasi pada masing-masing rhizosfir tanaman (Broeckling et al., 2008). Fitter \& Hay (1991) menyatakan pula bahwa pertambahan populasi mikroorganisme di rhizosfer dirangsang oleh bertambahnya konsentrasi berbagai bahan kimia yang bertindak sebagai sumber energi bagi mikroorganisme tersebut. 
Pengujian PGPR pada tanaman cabai merah dengan dosis $5 \mathrm{ml}, 7,5 \mathrm{ml}, 10 \mathrm{ml}$ dan 12,5 ml, menujukkan peningkatan jumlah buah dan bobot basah pada perlakuan 7,5 ml (Syamsiah \& Royani, 2014). Penelitian yang telah dilakukan sebelumnya oleh A'yun et al. (2013) diperoleh aplikasi PGPR dengan konsentrasi $10 \mathrm{ml} / \mathrm{L}$ pada tanaman cabai rawit dapat menurunkan intensitas serangan TMV (Tobacco Mosaic Virus) sampai 89,92\%, meningkatkan produksi tanaman cabai, dan dapat meningkatkan tinggi tanaman cabai rawit. Penelitian Iswati (2012) menunjukkan aplikasi PGPR dengan konsentrasi 12,5 $\mathrm{ml} / \mathrm{L}$ berpengaruh nyata terhadap tinggi tanaman dan panjang akar tanaman tomat, serta konsentrasi 7,5 ml/L dapat memaksimalkan jumlah daun dan jumlah akar pada tanaman tomat. Kurniawan (2018) menyatakan bahwa konsentrasi PGPR 20 ml.L-1 memberikan hasil terbaik terhadap tinggi, diameter dan panjang akar pada tanaman semai sengon (Paraserianthes falcataria L.).

Penambahan bahan organik pada media tanam bawang merah akan menciptakan suasana yang menyenangkan bagi mikroorganisme termasuk bakteri dalam hidupnya. Pupuk organik mempunyai fungsi penting bagi tanah yaitu untuk menggemburkan lapisan tanah permukaan (topsoil), meningkatkan populasi jasad renik tanah, mempertinggi daya serap dan daya simpan air yang secara keseluruhan akan meningkatkan kesuburan tanah (Widowati et al., 2005). Jasad renik seperti mikroba akan menguraikan bahan organik yang diaplikasikan ke tanah dan digunakan sebagai sumber energi (Fauzi, 2008).

Pupuk organik merupakan pupuk dengan bahan baku utama sisa mahluk hidup, seperti darah, tulang, kotoran, bulu, sisa tumbuhan atau limbah rumah tangga yang telah mengalami proses pembusukan. Kompos merupakan pupuk organik buatan manusia yang dibuat dari proses pembusukan sisa-sisa buangan mahluk hidup (tanaman maupun hewan). Kompos tidak hanya menambah unsur hara, tetapi juga menjaga fungsi tanah sehingga tanaman dapat tumbuh dengan baik (Yuwono, 2005). Kompos merupakan komponen untuk meningkatkan kesuburan tanah yang berperan penting dalam memperbaiki kerusakan fisik tanah akibat pemakaian pupuk anorganik (kimia) pada tanah secara berlebihan yang berakibat rusaknya struktur tanah dalam jangka waktu lama (Hartono et al., 2017). Pemberian pupuk kompos terutama akan memperbaiki sifat fisik tanah dimana tanah akan menjadi gembur aerasi dan drainase tanah menjadi lebih baik, dan perbaikan sifat fisik tanah akan semakin meningkatkan pertumbuhan akar tanaman (Noverita, 2005). 
Bahan organik seperti kompos dapat berperan langsung sebagai sumber hara tanaman setelah mengalami proses mineralisasi. Kompos mampu menyediakan makanan untuk mikroorganisme yang menjaga tanah dalam kondisi seimbang (Isroi, 2008), selanjutnya (Zainudin et al., 2014) menyatakan bahwa mikroorganisme seperti PGPR dapat mempengaruhi tanaman secara langsung dan tidak langsung, secara langsung yaitu pada proses fiksasi nitrogen, melarutkan fosfat, memproduksi siderofere dan hormone pertumbuhan, selain itu secara tidak langsung dapat memperbaiki kondisi pertumbuhan dengan beberapa mekanisme. PGPR mampu menghasilkan hormon tumbuhan seperti auxin, giberellin dan sitokinin, sebagai pelarut fosfat dan fiksasi nitrogen (Spaepen et al., 2009; Vessey, 2003).

(Kafrawi et al., 2017) telah memformulasi PGPR mengandung isolat-isolat yang menghasilkan auksin, nitrogen, dan phosfor yang diinokulasi pada tanaman bawang merah dan memberi pengaruh baik terhadap jumlah daun dan jumlah umbi. Belum tersedia data tentang interaksi konsentrasi PGPR dengan takaran pupuk organik yang terbaik dalam memacu pertumbuhan tanaman bawang merah sehingga dipandang perlu untuk melakukan penelitian terkait hal tersebut.

\section{BAHAN DAN METODE}

Penelitian berlangsung dari Maret hingga Desember 2020 di Kebun Penelitian Jurusan Budidaya Tanaman Tanaman Perkebunan, Politeknik Pertanian Negeri Pangkajene dan Kepulauan. Alat yang dgunakan adalah erlenmeyer daan gelas ukur. Bahan utama yang digunakan adalah pupuk kompos, benih bawang merah varietas Bima, PGPR berisi konsorsium berbagai isolate bakteri Bacillus spp yang diisolasi dari perakaran bawang merah di sentra penanaman bawang merah di pulau Sulawesi.

\section{Metodologi}

Penelitian ini menggunakan Rancangan Faktorial dengan dasar Rancangan Acak Kelompok (RAK) dan menggunakan 2 (dua) faktor perlakuan, perlakuan pertama adalah takaran kompos yang terdiri dari 4 level yaitu: tanpa pemberian kompos, tanah + kompos $1: 1, \operatorname{tanah}+$ kompos $1: 2$ dan tanah + kompos $2: 1$. Perlakuan kedua adalah konsentrasi mikroba PGPR (P) dengan 3 taraf yaitu: Konsentrasi $10 \mathrm{ml} . \mathrm{L}^{-1}$ air, $20 \mathrm{ml} . \mathrm{L}^{-1}$ air, dan $30 \mathrm{ml} . \mathrm{L}^{-1}$ air. Terdapat 12 kombinasi perlakuan yang terdiri dari 2 unit penelitian dan diulang kedalam 3 kelompok, sehingga terdapat 72 unit tanaman penelitian. 


\section{Kultur Isolat Mikroba PGPR}

Isolat mikroba MG14 diperbanyak dengan cara ditumbuhkan pada media Nutrient Agar (NA) dengan melakukan penggoresan sebanyak 8 kali secara zig-zag. Setelah diinkubasi selama 72 jam pada $28 \pm 2^{\circ} \mathrm{C}$, isolat bakteri pada media NA diencerkan dalam larutan 3,64 $\mathrm{g}$ $\mathrm{MgSO}_{4} 7 \mathrm{H}_{2} 0 \mathrm{~L}^{-1}\left(3,64 \mathrm{~g}=[0.01] \times 1 \mathrm{~L}\right.$ aquades x 364,46 $\left.{ }^{\text {massa relative }}\right)$ agar dinding sel bakteri tidak mengalami lisis, filtrat kultur bakteri kemudian dihitung kepadatan populasinya dengan menggunakan spektrofotometer pada panjang gelombang 660 nano meter (nm), dengan optical dencity 0,06 $\left(10^{8}\right)$. Tambahkan bahan formulasi berupa larutan Carboxyl Metil Cellulose (CMC), glycerol, Na alginat, tween 80, dan sorbitol yang berfungsi sebagai perekat, pelindung, pengisi, perata dan pengemulsi. Selanjutnya isolat-isolat tersebut dicampur dalam wadah (botol) steril dengan volume 1 liter, lalu wadah (botol) ditutup rapat. Inkubasikan selama tiga hari pada shaker. Formulasi dianggap berhasil jikalau tercium wangi spesifik pada formulasi setelah masa inkubasi.

\section{Persiapan Media Tanam}

Pupuk kompos yang telah siap untuk digunakan kemudian dicampur tanah dengan perbandingan sesuai perlakuan yang ditetapkan pada desain percobaan. Campur secara merata, kemudian masukkan kedalam planterbag yang berukuran $17 \mathrm{~cm}$ x $25 \mathrm{~cm}$.

\section{Persiapan Bahan Tanam dan Penanaman}

Umbi lapis bawang merah yang digunakan adalah umbi bibit yang telah kawak yaitu memiliki umur simpan minimal 1-1,5 bulan dan memiliki ukuran yang besar yaitu lebih besar dari 5 g. Sayat titik tumbuh umbi lapis dengan pisau bersih dan tajam untuk mematahkan dormansi umbi lapis lalu keringanginkan selama 1 jam sebelum akhirnya siap untuk ditanam. Proses penanaman dilakukan dengan cara menancapkan benih umbi lapis kedalam media tanam tepat dibagian tengah permukaan planterbag kemudian ditutup dengan tanah kurang lebih $1 \mathrm{~cm}$.

\section{Perlakuan PGPR}

Penyiraman dilakukan saat tanaman bawang merah telah berumur 2 dan 4 minggu, sebanyak $500 \mathrm{ml}$ PGPR per tanaman, disiramkan pada masing-masing planterbag sesuai konsentrasi perlakuan yang telah ditetapkan. 


\section{HASIL DAN PEMBAHASAN}

\section{Tinggi Tanaman}

Pengamatan tinggi tanaman dan sidik ragam menunjukkan bahwa perlakuan tunggal takaran kompos berpengaruh sangat nyata dan kombinasinya dengan perlakuan konsentrasi mikroba PGPR berpengaruh nyata terhadap tinggi tanaman bawang merah pada 3 bulan setelah tanam (bst) sedangkan perlakuan tunggal konsentrasi mikroba PGPR berpengaruh tidak nyata.

Tabel 1. Rata-rata Tinggi Tanaman $(\mathrm{cm})$ Bawang Merah pada Kombinasi Perlakuan Takaran kompos dan Konsentrasi Mikroba PGPR 3 bulan setelah tanam (bst).

\begin{tabular}{|c|c|c|c|c|c|}
\hline \multirow{2}{*}{ Tanah + Kompos } & \multicolumn{3}{|c|}{ Konsentrasi PGPR } & \multirow{2}{*}{ Rata-rata } & \multirow{2}{*}{$\begin{array}{l}\text { NP JBD } 0.05 \\
\quad(T \times \text { x })\end{array}$} \\
\hline & $10 \mathrm{ml} . \mathrm{L}^{-1}$ & $20 \mathrm{ml} . \mathrm{L}^{-1}$ & $30 \mathrm{ml} . \mathrm{L}^{-1}$ & & \\
\hline \multirow[t]{2}{*}{$1: 0$} & $37.57^{\mathrm{a}}$ & $37.87^{\mathrm{a}}$ & $31.90^{\mathrm{b}}$ & 35.78 & \multirow{3}{*}{$\begin{array}{l}3.99 \\
4.20 \\
4.32\end{array}$} \\
\hline & $\mathrm{x}$ & ${ }^{31.0} \mathrm{x}$ & 31.90 & $\begin{array}{r}35.10 \\
y\end{array}$ & \\
\hline $1: 1$ & $\begin{array}{r}39.75^{\mathrm{a}} \\
\mathrm{x}\end{array}$ & $38.87^{\mathrm{a}}$ & $42.63^{\mathrm{a}}$ & $\begin{array}{r}40.42 \\
x\end{array}$ & \\
\hline $1: 2$ & $\begin{array}{r}39.70^{a} \\
x\end{array}$ & $39.17^{a}$ & $38.97^{\mathrm{a}}$ & $\begin{array}{r}39.28 \\
\mathrm{x}\end{array}$ & \\
\hline $2: 1$ & $\begin{array}{r}39.43^{\mathrm{a}} \\
\mathrm{x} \\
\end{array}$ & $\begin{array}{r}39.33^{\mathrm{a}} \\
\mathrm{x} \\
\end{array}$ & $38.83^{\mathrm{a}}$ & $\begin{array}{r}39.20 \\
\mathrm{x}\end{array}$ & \\
\hline Rata-rata & 39.11 & 38.81 & 38.08 & & \\
\hline NP JBD $0.01(\mathrm{~T})$ & 3.14 & 3.28 & 3.37 & & \\
\hline
\end{tabular}

Kompos merupakan salah satu pupuk organik yang digunakan pada pertanian untuk mengurangi penggunaan pupuk anorganik. Penggunaan kompos dapat memperbaiki sifat fisik tanah dan mikrobiologi tanah (Syam, 2003)sedangkan PGPR (Plant Grwoth Promoting Rhizobacteria) adalah mikroba tanah yang berada di sekitar akar tanaman baik secara langsung maupun tidak langsung terlibat dalam memacu pertumbuhan serta perkembangan tanaman (Ahemad \& Kibret, 2014). Kombinasi perlakuan takaran tanah + kompos (1:1) dengan konsentrasi PGPR $30 \mathrm{ml} . \mathrm{L}^{-1}$ menghasilkan tinggi tanaman terbaik. Hal ini disebabkan oleh takaran media tanah dan kompos yang seimbang mendukung aktifitas mikroba PGPR pada konsentrasi tinggi. Pada pertumbuhan tinggi tanaman bawang, salah satu unsur hara yang berperan adalah Nitrogen. Sumber nitrogen ditemukan pada bahan organik kompos yang ada pada media tanam bawang merah berupa kompos. Kompos menyediakan unsur $\mathrm{N}$ organik 
(Widarti et al., 2015) sedangkan mikroba yang terkandung dalam PGPR mampu semakin meningkatkan kandungan nitrogen pada media tanam bawang merah. Widawati et al., (2003) menyatakan bahwa tanah yang mengandung bahan organik dan unsur hara menjadi sumber bakteri untuk pembentukan sel, asam nukleat, serta proses metabolisme. Tersedianya bahan organik menyebabkan PGPR dapat menjalankan tugasnya sehingga dapat berpengaruh terhadap tinggi tanaman (Hidayat et al., 2013). Selain berfungsi sebagai biostimulan, PGPR juga sebagai penyedia hara dengan mengikat $\mathrm{N} 2$ di udara secara asimbiosis dan melarutkan hara $\mathrm{P}$ dalam tanah (Marom et al., 2017).

\section{Jumlah Daun}

Pengamatan jumlah daun dan sidik ragam menunjukkan bahwa perlakuan tunggal takaran kompos dan konsentrasi mikroba PGPR berpengaruh nyata sedangkan kombinasi kedua perlakuan berpengaruh sangat nyata terhadap jumlah daun tanaman bawang merah pada 3 bulan setelah tanam (bst).

Tabel 2. Rata-rata Jumlah Daun (helai) Bawang Merah pada Kombinasi Perlakuan Takaran kompos dan Konsentrasi Mikroba PGPR 3 bst

\begin{tabular}{|c|c|c|c|c|c|}
\hline \multirow{2}{*}{ Tanah + Kompos } & \multicolumn{3}{|c|}{ Konsentrasi PGPR } & \multirow{2}{*}{ Rata-rata } & \multirow{2}{*}{$\begin{array}{l}\text { NP JBD } 0.01 \\
\quad(T \times P)\end{array}$} \\
\hline & $10 \mathrm{ml} . \mathrm{L}^{-1}$ & $20 \mathrm{ml} . \mathrm{L}^{-1}$ & $30 \mathrm{ml} . \mathrm{L}^{-1}$ & & \\
\hline \multirow{2}{*}{$1: 0$} & \multirow{2}{*}{$23.17^{\mathrm{a}}$} & \multirow{2}{*}{$27.33_{x}^{a b}$} & \multirow{2}{*}{$19.67_{y}^{b}$} & 25.25 & \multirow{2}{*}{$\begin{array}{l}4.84 \\
5.06\end{array}$} \\
\hline & & & & $\begin{array}{r}25.25 \\
y\end{array}$ & \\
\hline \multirow[t]{2}{*}{$1: 1$} & $26.33^{\mathrm{a}}$ & $24.50^{\mathrm{a}}$ & $26.17^{\mathrm{a}}$ & 25.42 & \multirow[t]{6}{*}{5.19} \\
\hline & xy & & & $\mathrm{x}$ & \\
\hline $1: 2$ & $26.83^{\mathrm{a}}$ & $23.00^{\mathrm{b}}$ & $24.67^{\mathrm{ab}}$ & 24.92 & \\
\hline & $x y$ & & & $x y$ & \\
\hline \multirow[t]{2}{*}{$2: 1$} & $29.00^{\mathrm{a}}$ & $25.33^{\mathrm{a}}$ & $25.33^{\mathrm{a}}$ & \multirow{2}{*}{$\begin{array}{r}27.17 \\
\mathrm{x}\end{array}$} & \\
\hline & & & & & \\
\hline Rata-rata & $26.33 \mathrm{~A}$ & $25.04 a b$ & $23.96 \mathrm{~B}$ & & \\
\hline NP $0.05 \mathrm{JBD}(\mathrm{T})$ & 2.05 & 2.16 & 2.22 & & \\
\hline NP $0.05 \mathrm{JBD}(\mathrm{P})$ & 1.78 & 1.87 & 1.92 & & \\
\hline
\end{tabular}

Keterangan: Angka-angka yang diikuti oleh huruf yang sama pada baris $(\mathrm{a}, \mathrm{b})$ dan kolom $(\mathrm{x}, \mathrm{y})$ berbeda tidak nyata pada taraf uji $\alpha=0,05$

Berbanding terbalik dengan tinggi tanaman bawang merah, pembentukan jumlah daun terbanyak justru diperoleh dari kombinasi perlakuan takaran tanah + kompos (2:1) dengan konsentrasi PGPR $10 \mathrm{ml} . \mathrm{L}^{-1}$. Kandungan bahan organik yang tinggi pada media tanam bawang merah dengan konsentrasi mikroba PGPR yang rendah cukup efektif menyediakan unsur hara untuk pertumbuhan vegetatif. Adanya interaksi yang saling menguntungkan antara PGPR dan 
kompos berdampak pada peningkatan jumlah daun dan pada tanaman bawang merah. Semakin tersedianya nutrien bagi bakteri PGPR maka bakteri PGPR akan sukses mengkoloni bagian akar tanaman sehingga dapat menguntungkan bagi pertumbuhan tanaman (Widyati, 2013). Semakin tinggi pemberian bahan organik berupa kompos dapat menurunkankan pemberian konsentrasi PGPR (Gholami et al., 2009). Pada pembentukan daun, unsur $\mathrm{N}$ sangat berperan karena dapat meningkatkan proses fotosintesis yang berpengaruh pada pembentukan helai daun. Beberapa mikroorganisme dapat berperan sebagai penambat unsur N sehingga dapat diserap langsung oleh tanaman (Ginting et al., 1996).

\section{Bobot Umbi Brangkasan Segar}

Pengamatan bobot umbi brangkasan segar dan sidik ragam menunjukkan bahwa perlakuan tunggal takaran kompos berpengaruh sangat nyata dan kombinasinya dengan perlakuan konsentrasi mikroba PGPR berpengaruh nyata terhadap bobot umbi brangkasan segar bawang merah pada 3 bulan setelah tanam (bst) sedangkan perlakuan tunggal konsentrasi mikroba PGPR berpengaruh tidak nyata.

Tabel 3. Rata-rata Bobot Umbi Brangkasan Segar (g) Bawang Merah pada Kombinasi Perlakuan Takaran kompos dan Konsentrasi Mikroba PGPR 3 bst

\begin{tabular}{|c|c|c|c|c|c|}
\hline \multirow{2}{*}{ Tanah + Kompos } & \multicolumn{3}{|c|}{ Konsentrasi PGPR } & \multirow{2}{*}{ Rata-rata } & \multirow{2}{*}{$\begin{array}{l}\text { NP JBD } 0.05 \\
\quad(T \times P)\end{array}$} \\
\hline & $10 \mathrm{ml} . \mathrm{L}^{-1}$ & $20 \mathrm{ml} . \mathrm{L}^{-1}$ & $30 \mathrm{ml} . \mathrm{L}^{-1}$ & & \\
\hline \multirow{2}{*}{$1: 0$} & \multirow{2}{*}{$\begin{array}{c}21.57^{\mathrm{ab}} \\
\mathrm{y}\end{array}$} & \multirow{2}{*}{$\begin{array}{r}28.06^{\mathrm{a}} \\
x\end{array}$} & \multirow{2}{*}{$19.55^{b}$} & \multirow{2}{*}{$\begin{array}{r}24.82 \\
y\end{array}$} & 7.07 \\
\hline & & & & & 7.43 \\
\hline \multirow[t]{2}{*}{$1: 1$} & $32.64^{\mathrm{a}}$ & $25.05^{\mathrm{b}}$ & $32.21^{\mathrm{a}}$ & \multirow{2}{*}{$\begin{array}{r}28.84 \\
x\end{array}$} & 7.65 \\
\hline & $\mathrm{x}$ & & & & \\
\hline \multirow[t]{2}{*}{$1: 2$} & $26.38^{\mathrm{a}}$ & $19.75^{\mathrm{a}}$ & $26.56^{\mathrm{a}}$ & \multirow{2}{*}{\multicolumn{2}{|c|}{$\begin{array}{r}23.06 \\
x y\end{array}$}} \\
\hline & & & & & \\
\hline \multirow[t]{2}{*}{$2: 1$} & $28.16^{\mathrm{a}}$ & $27.60^{\mathrm{a}}$ & $29.19^{\mathrm{a}}$ & \multirow{3}{*}{$\begin{array}{r}27.88 \\
\mathrm{Xy}\end{array}$} & \\
\hline & $\mathrm{xy}$ & & & & \\
\hline Rata-rata & 27.19 & 25.11 & 26.88 & & \\
\hline NP $0.01 \mathrm{JBD}(\mathrm{T})$ & 0.36 & 0.38 & 0.39 & & \\
\hline
\end{tabular}

Pembentukan biomassa berupa bobot umbi brangkasan segar tertinggi diperoleh dari kombinasi perlakuan takaran tanah + kompos (1:1) dengan konsentrasi PGPR 10 ml.L-1. Berat basah tanaman berkaitan dengan penimbunan hasil fotosintesa dan air yang mampu diserap oleh tanaman (Widarti et al., 2015). Penambahan bahan organik pada media tanam menyebabkan 
struktur tanah menjadi gembur yang secara langsung meningkatkan pori tanah yang menyebabkan akar tanaman leluasa mudah dan berkembang. (Sertua et al., 2014)menjelaskan bahwa bahan organik membuat tanah menjadi gembur sehingga perkembangan akar tanaman lebih optimal. Prasetyo et al. (2014) menambahkan bahwa peningkatan pori tanah akan menyebabkan ketersediaan udara dan penetrasi akar semakin meningkat. Udara yang berada di dalam tanah digunakan akar dalam berkembang.

Media tanam dengan takaran tanah dan kompos yang seimbang mendukung aktifitas mikroba PGPR pada konsentrasi rendah. Selain dipengaruhi oleh ketersediaan hara, pertumbuhan tanaman juga dipengaruhi oleh mikroorganisme yang terdapat pada media tanam. Semakin tinggi mikroba yang diberikan pada media tanam, ini berarti jumlah mikroorganisme juga semakin banyak dan membutuhkan makanan. Pada kondisi seperti ini bisa terjadi persaingan antar mikroorganisme dan tanaman dalam menyerap nutrisi (Ginting et al., 1996). Mikroorganisme berperan dalam mengubah senyawa organik menjadi senyawa anorganik menjadi ion-ion yang dapat diserap langsung oleh tanaman (Elpawati et al., 2015). Kekurangan nitrogen seringkali menghambat pertumbuhan tanaman pada berbagai fase pertumbuhannya.

\section{Bobot Umbi Brangkasan Askip Kering}

Pengamatan bobot umbi brangkasan askip kering dan sidik ragam menunjukkan bahwa perlakuan tunggal takaran kompos berpengaruh sangat nyata dan kombinasinya dengan perlakuan konsentrasi mikroba PGPR berpengaruh nyata terhadap bobot umbi brangkasan askip kering bawang merah pada 3 bulan setelah tanam (bst) sedangkan perlakuan tunggal konsentrasi mikroba PGPR berpengaruh tidak nyata.

Mikroba PGPR yang diaplikasikan mampu membantu tanaman dalam menyerap unsur hara dalam tanah sesuai dengan peran dari PGPR sebagai biofertilizer yang membantu tanaman dalam mempercepat penyerapan unsur hara (Rai, 2006), sama halnya dengan bobot umbi brangkasan segar, pembentukan biomassa berupa bobot umbi brangkasan askip kering tertinggi juga diperoleh dari kombinasi perlakuan takaran tanah + kompos (1:1) dengan konsentrasi PGPR $10 \mathrm{ml} . \mathrm{L}^{-1}$. Berat kering tanaman berkaitan dengan hasil fotosintat yang mampu diserap tanaman (Widarti et al., 2015). Sejalan dengan penelitian Putrie (2016) yang menyatakan bahwa penggunaan agen PGPR meningkatkan vigor benih, tinggi tanaman, berat basah, serta berat kering tanaman. 
Tabel 4. Rata-rata Bobot Umbi Brangkasan Askip Kering (g) Bawang Merah pada Kombinasi Perlakuan Takaran kompos dan Konsentrasi Mikroba PGPR 3 bst

\begin{tabular}{|c|c|c|c|c|c|}
\hline \multirow{2}{*}{ Tanah + Kompos } & \multicolumn{3}{|c|}{ Konsentrasi PGPR } & \multirow{2}{*}{ Rata-rata } & \multirow{2}{*}{$\begin{array}{l}\text { NP JBD } 0.05 \\
\quad(T \times P)\end{array}$} \\
\hline & $10 \mathrm{ml} . \mathrm{L}^{-1}$ & $20 \mathrm{ml} . \mathrm{L}^{-1}$ & $30 \mathrm{ml} . \mathrm{L}^{-1}$ & & \\
\hline \multirow{2}{*}{$1: 0$} & $13.10^{\mathrm{ab}}$ & $964^{b}$ & \multirow{2}{*}{$15.02^{\mathrm{a}}$} & 1137 & \multirow{2}{*}{$\begin{array}{l}3.72 \\
3.91\end{array}$} \\
\hline & $y$ & $y$ & & $\mathrm{z}$ & \\
\hline \multirow[t]{2}{*}{$1: 1$} & $18.95^{\mathrm{ab}}$ & $15.82^{\mathrm{a}}$ & $18.46^{\mathrm{a}}$ & 17.39 & \multirow[t]{6}{*}{4.02} \\
\hline & $\mathrm{x}$ & & & $\mathrm{x}$ & \\
\hline \multirow{2}{*}{$1: 2$} & $14.55^{\mathrm{ab}}$ & $17.63^{\mathrm{a}}$ & $13.21^{\mathrm{b}}$ & \multirow{2}{*}{$\begin{array}{r}16.09 \\
y z\end{array}$} & \\
\hline & $\mathrm{y}$ & & & & \\
\hline \multirow{2}{*}{$2: 1$} & $17.31^{\mathrm{ab}}$ & $15.13^{\mathrm{a}}$ & $17.27^{\mathrm{a}}$ & \multirow{3}{*}{$\begin{array}{r}16.22 \\
\mathrm{xy}\end{array}$} & \\
\hline & $\begin{array}{r}17.01 \\
\mathrm{xy}\end{array}$ & $\begin{array}{r}15.15 \\
\mathrm{y}\end{array}$ & ${ }^{11.21}$ & & \\
\hline Rata-rata & 15.98 & 14.56 & 15.99 & & \\
\hline NP $0.01 \mathrm{JBD}(\mathrm{T})$ & 2.315 & 2.26 & 2.32 & & \\
\hline
\end{tabular}

Keterangan: Angka-angka yang diikuti oleh huruf yang sama pada baris $(\mathrm{a}, \mathrm{b})$ dan kolom $(\mathrm{x}, \mathrm{y})$ berbeda tidak nyata pada taraf uji $\alpha=0,05$

\section{Susut Bobot Tanaman}

Pengamatan susut bobot tanaman dan sidik ragam menunjukkan bahwa kedua perlakuan tunggal yaitu takaran kompos dan konsentrasi mikroba PGPR berpengaruh tidak nyata terhadap susut bobot tanaman bawang merah pada 3 bulan setelah tanam (bst) tetapi kombinasi kedua perlakuan berpengaruh sangat nyata.

Tabel 5. Rata-rata Susut Bobot Tanaman (g) Bawang Merah pada Kombinasi Perlakuan Takaran kompos dan Konsentrasi Mikroba PGPR 3 bst

\begin{tabular}{|c|c|c|c|c|c|}
\hline \multirow{2}{*}{ Tanah + Kompos } & \multicolumn{3}{|c|}{ Konsentrasi PGPR } & \multirow{2}{*}{ Rata-rata } & \multirow{2}{*}{$\begin{array}{l}\text { NP JBD } 0.01 \\
\quad(T \times P)\end{array}$} \\
\hline & $10 \mathrm{ml} . \mathrm{L}^{-1}$ & $20 \mathrm{ml} . \mathrm{L}^{-1}$ & $30 \mathrm{ml} . \mathrm{L}^{-1}$ & & \\
\hline \multirow{2}{*}{$1: 0$} & \multirow{2}{*}{$\begin{array}{r}8.47^{\mathrm{b}} \\
\mathrm{x}\end{array}$} & \multirow{2}{*}{$18.42^{\mathrm{a}}$} & \multirow{2}{*}{$4.53^{\mathrm{b}}$} & \multirow{2}{*}{13.45} & \multirow{3}{*}{$\begin{array}{l}8.77 \\
9.17 \\
9.41\end{array}$} \\
\hline & & & & & \\
\hline $1: 1$ & $\begin{array}{r}13.68^{\mathrm{a}} \\
\mathrm{x}\end{array}$ & $9.23^{\mathrm{a}}$ & $\begin{array}{r}13.76^{\mathrm{a}} \\
\mathrm{x}\end{array}$ & 11.45 & \\
\hline $1: 2$ & $\begin{array}{r}11.83^{\mathrm{b}} \\
\mathrm{x}\end{array}$ & $2.12^{\mathrm{c}}$ & $\begin{array}{r}13.35^{\mathrm{a}} \\
\mathrm{x}\end{array}$ & 6.97 & \\
\hline $2: 1$ & $\begin{array}{r}10.85^{\mathrm{a}} \\
\mathrm{x}\end{array}$ & $12.47^{\mathrm{a}}$ & $\begin{array}{r}11.92^{\mathrm{a}} \\
\mathrm{x}\end{array}$ & 11.66 & \\
\hline Rata-rata & 11.21 & 10.56 & 10.89 & & \\
\hline
\end{tabular}

Keterangan: Angka-angka yang diikuti oleh huruf yang sama pada baris (a,b) dan kolom (x,y) berbeda tidak nyata pada taraf uji $\alpha=0,05$ 
Susut bobot tanaman tertinggi diperoleh dari kombinasi perlakuan takaran tanah tanpa penambahan kompos (1:0) dengan konsentrasi PGPR $20 \mathrm{ml} . \mathrm{L}^{-1}$. Tanpa penambahan bahan organik pada media tanam bawang merah menyebabkan rendahnya unsur hara yang dapat terangkut ke dalam tanaman dan secara langsung meningkatkan kadar air biomassa tanaman, ketika dikeringanginkan maka kehilangan air mempertinggi susut bobot tanaman. (Mutia, 2019), kadar air bawang merah yang terlalu tinggi dapat menyebabkan mudahnya terjadi kebusukan dan kerusakan seperti munculnya akar sedangkan kadar air bawang merah yang terlalu rendah dapat berakibat pada susut bobot yang tinggi yang menyebabkan penurunan kualitas dari umbi.

\section{Bobot Umbi Protolan Kering Askip}

Pengamatan bobot umbi protolan kering askip dan sidik ragam menunjukkan bahwa perlakuan tunggal takaran kompos dan konsentrasi mikroba PGPR berpengaruh sangat nyata sedangkan kombinasi kedua perlakuan berpengaruh nyata terhadap bobot umbi protolan kering askip tanaman bawang merah pada 3 bulan setelah tanam (bst).

Tabel 6. Rata-rata Bobot Umbi Protolan Kering Askip (g) Bawang Merah pada Kombinasi Perlakuan Takaran kompos dan Konsentrasi Mikroba PGPR 3 bst

\begin{tabular}{|c|c|c|c|c|c|}
\hline \multirow{2}{*}{ Tanah + Kompos } & \multicolumn{3}{|c|}{ Konsentrasi PGPR } & \multirow{2}{*}{ Rata-rata } & \multirow{2}{*}{$\begin{array}{l}\text { NP JBD } 0.05 \\
\quad(\mathrm{~T} \times \mathrm{P})\end{array}$} \\
\hline & $10 \mathrm{ml} . \mathrm{L}^{-1}$ & $20 \mathrm{ml} . \mathrm{L}^{-1}$ & $30 \mathrm{ml} . \mathrm{L}^{-1}$ & & \\
\hline \multirow{2}{*}{$1: 0$} & \multirow{2}{*}{$\begin{array}{c}5.67^{\mathrm{ab}} \\
\mathrm{z}\end{array}$} & \multirow{2}{*}{$4.40^{\mathrm{b}}$} & \multirow{2}{*}{$\begin{array}{r}7.05^{a} \\
x\end{array}$} & \multirow{2}{*}{$\begin{array}{r}5.04 \\
\mathrm{z}\end{array}$} & \multirow{2}{*}{$\begin{array}{l}2.49 \\
2.61\end{array}$} \\
\hline & & & & & \\
\hline \multirow[t]{2}{*}{$1: 1$} & $11.54^{\mathrm{a}}$ & $8.79^{b}$ & $8.51^{b}$ & \multirow{2}{*}{$\begin{array}{r}10.17 \text { x } \\
\text {. }\end{array}$} & \multirow[t]{2}{*}{2.68} \\
\hline & & & & & \\
\hline \multirow[t]{2}{*}{$1: 2$} & $7.92^{\mathrm{a}}$ & $6.51^{\mathrm{a}}$ & $8.36^{\mathrm{a}}$ & \multirow{2}{*}{\multicolumn{2}{|c|}{$\begin{array}{r}7.21 \\
\mathrm{y}\end{array}$}} \\
\hline & $\mathrm{y}$ & $\mathrm{y}$ & & & \\
\hline \multirow[t]{2}{*}{$2: 1$} & $8.46^{\mathrm{a}}$ & $7.83^{\mathrm{ab}}$ & $9.98^{b}$ & \multirow{2}{*}{\multicolumn{2}{|c|}{$\begin{array}{r}8.14 \\
\mathrm{y}\end{array}$}} \\
\hline & $\mathrm{y}$ & $x y$ & $\mathrm{X}$ & & \\
\hline Rata-rata & $8.40 \mathrm{a}$ & $6.88 \mathrm{~b}$ & $8.47 \mathrm{a}$ & & \\
\hline $\mathrm{NP} 0.01 \mathrm{JBD}(\mathrm{T})$ & 0.38 & 0.40 & 0.41 & & \\
\hline NP $0.01 \mathrm{JBD}(\mathrm{P})$ & 1.25 & 1.30 & 1.34 & & \\
\hline
\end{tabular}

Pembentukan biomassa berupa bobot umbi protolan kering askip tertinggi diperoleh dari kombinasi perlakuan takaran tanah + kompos (1:1) dengan konsentrasi PGPR 10 ml.L ${ }^{-1}$. Terbentuknya bobot kering diketahui dapat terjadi bila fotosintesis lebih besar dari respirasi. Hal ini dibuktikan dengan adanya aktivitas bakteri dalam tubuh tanaman dalam perannya sebagai fitohormon terutama IAA yang diduga dapat meningkatkan permeabilitas dinding sel yang akan 
meningkatkan penyerapan unsur hara pembentuk klorofil yang sangat diperlukan untuk meningkatkan fotosintesis dan berpengaruh pada hasil produksi tanaman. Selain itu, diduga akibat dari kandungan unsur hara dari kompos yang diberikan dan bersamaan dengan adanya bantuan bakteri di dalam media tanaman, mampu diserap tanaman untuk proses metabolisme seperti pembentukan karbohidrat yang sebagian besar ditranslokasikan untuk pembentukan umbi dan pada fase ini kalium berperan dalam pembentukan dan pembesaran umbi (Tuhuteru et al., 2017).

\section{KESIMPULAN}

1. Tanaman tertinggi diperoleh dari kombinasi perlakuan media tanah berkompos $(1: 1)$ dengan konsentrasi PGPR $30 \mathrm{ml} . \mathrm{L}^{-1}(42,63 \mathrm{~cm})$

2. Jumlah daun per tanaman terbanyak diperoleh dari kombinasi perlakuan media tanah berkompos (2:1) dengan konsentrasi PGPR 10 ml.L ${ }^{-1}$ (29 helai)

3. Hasil tertinggi dari pengukuran bobot umbi brangkasan segar, bobot umbi brangkasan kering askip, dan bobot umbi protolan kering askip semua diperoleh dari kombinasi perlakuan media tanah berkompos (1:1) dengan konsentrasi PGPR 10 ml.L $\mathrm{L}^{-1}$ masingmasing sebesar 32,64 g, 19,95 g, dan 11,54 g

4. Susut bobot tanaman tertinggi diperoleh dari kombinasi perlakuan media tanah tanpa penambahan kompos dengan konsentrasi PGPR 20 ml.L ${ }^{-1}(18,42 \mathrm{~g})$

\section{DAFTAR PUSTAKA}

A’yun, K. Q., Hadiastono, T., \& Martosudiro, M. (2013). Pengaruh penggunaan PGPR (Plant Growth Promoting Rhizobacteria) terhadap TMV (Tobacco Mosaic Virus), Pertumbuhan, dan Produksi pada Tanaman Cabai Rawit (Capsicum frutescens L.). Jurnal HPT, 1(1), 4756.

Ahemad, M., \& Kibret, M. (2014). Mechanisms and applications of plant growth promoting rhizobacteria: Current perspective. Journal of King Saud University - Science, 26(1), 1-20. https://doi.org/10.1016/j.jksus.2013.05.001

Badan Pusat Statistik dan Direktorat Jenderal Hortikultura. (2011). Statistik Ekspor Impor Sayuran tahun 2011. BPS dan Direktorat Jenderal Hortikultura.

Broeckling, C. D., Broz, A. K., Bergelson, J., Manter, D. K., \& Vivanco, J. M. (2008). Root exudates regulate soil fungal community composition and diversity. Applied and Environmental Microbiology, 74(3), 738-744. https://doi.org/10.1128/AEM.02188-07 
Dewi, Ratna, \& Intan. (2007). Rhizobacteria Pendukung Pertumbuhan Tanaman. Makalah . Jurusan Budidaya Tanaman, Program Studi Agronomi, Fakultas Pertanian, Universitas Padjajaran, Bandung.

Elpawati, E., Dara, S. D., \& Dasumiati, D. (2015). Optimalisasi Penggunaan Pupuk Kompos dengan Penambahan Effective Microorganism 10 (Em10) pada Produktivitas Tanaman Jagung (Zea mays L.). AL-Kauniyah: Jurnal Biologi, 8(2), 77-87. https://doi.org/10.15408/kauniyah.v8i2.2693

Fauzi, A. (2008). Analisa Kadar Unsur Hara Karbon Organik dan Nitrogen di dalamTanah Perkebunan Kelapa Sawit Bengkalis Riau. Amd. TA. Universitas Sumatera Utara, Medan.

Fitter, A. H., \& Hay, R. K. M. (1991). Fisiologi Lingkungan Tanaman ((terjemaha). . Gadjah Mada University Press. Yogyakarta.

Gholami, A., Shahsavani, S., \& Nezarat, S. (2009). Effect of Plant Growth Promoting Rhizobacteria (PGPR) on Germination,Seedling Growth and Yeild of Maize. World Academy of Science, Engineering and Technology, 49, 19-24.

Gibson, A. H. (1981). Current Perspectives in Nitrogen Fixation. Proceeding of the Fourth International Symposium on Nitrogen Fixation, 534.

Ginting, R. C. B., Sarawati, R., \& Husen, E. (1996). Pupuk Organik dan PupukHayati. Balai Besar Litbang Sumberdaya Lahan Pertanian. Bogor.

Hartono, J. S. S., Same, M., \& Parapasan, Y. (2017). Peningkatan Mutu Kompos Kiambang MelaluiAplikasi Teknologi Hayati dan Kotoran Ternak Sapi. Jurnal Penelitian Pertanian Terapan, 14(3), 196-202. https://doi.org/10.25181/jppt.v14i3.160

Hidayat, C., Dedeh, H., Arief, Nurbity, A., \& Sauman., J. (2013). Inokulasi Fungsi Mikoroza Arnuskula dan mycorrhiza helperbacteria pada Andisol yang Diberi Bahan Organik utuk Meningkatkan Stabilitas Agregat Tanah, Serapan N dan P dan Hasil Taaman Kentang. Indonesian. Journal of Applied Science., 3(2), 26-41.

Isroi. (2008). Pengomposan Limbah Kakao. Http://www.Isroi.Org. Diakses Tanggal 3 April 2020.

Iswati, R. (2012). Pengaruh Dosis Formula Pgpr Asal Perakaran Bambu Terhadap Pertumbuhan Tanaman Tomat (Solanum Lycopersicum syn). Jurnal Agroteknotropika, 1(1).

Kafrawi, Nildayanti, K, Z., \& Baharuddin. (2017). Comparison of IAA Production by Shallot Rhizosphere Isolated Bacteria in Solid and Liquid Media and Their Effect on Shallot Plant Growth. Journal of Microbial \& Biochemical Technology, 09(06). https://doi.org/10.4172/1948-5948.1000375

Kementan. (2016). Outlook Bawang Merah Komoditas Pertanian Subsektor Hortikultura. Pusat Data dan Sistem Informasi Pertanian, Sekretariat Jenderal - Kementerian Pertanian. 
Lebuhn, M., Heulin, T., \& Hartmann, A. (1997). Production of auxin and other indolic and phenolic compounds by Paenibacillus polymyxa strains isolated from different proximity to plant roots. FEMS Microbiology Ecology, 22, 325-334.

Marom, N., Rizal, F., \& Bintoro, M. (2017). Uji Efektivitas Saat Pemberian dan Konsentrasi PGPR (Plant Growth Promoting Rhizobacteria) terhadap Produksi dan Mutu Benih Kacang Tanah (Arachis hypogaea L.). Agriprima : Journal of Applied Agricultural Sciences, 1(2), 174-184. https://doi.org/10.25047/agriprima.v1i2.43

Mutia, A. K. (2019). Pengaruh Kadar Air Awal pada Bawang Merah (Allium ascalonicum L.) terhadap Susut Bobot dan Tingkat Kekerasan Selama Penyimpanan pada Suhu Rendah. Gorontalo Agriculture Technology Journal, 2(1), 30-37. https://doi.org/10.32662/gatj.v2i1.538

Noverita, S. V. (2005). Pengaruh pemberian nitrogen dan kompos terhadap komponen pertumbuhan tanaman lidah buaya (Aloe vera). Jurnal Penelitian Bidang Pertanian, 3(3), $57-67$.

Prasetyo, Y., Djatmiko, H., \& Sulistyaningsih, N. (2014). Pengaruh Kombinasi Bahan Baku Dan Dosis Biochar Terhadap Perubahan Sifat Fisika Tanah Pasiran Pada Tanaman Jagung (Zea mays L.). Berkala Ilmiah Pertanian, 1(1), 1-5.

Putrie, R. T. W. (2016). Plant Growth Promoting Rhizobacteria (PGPR) Penghasil Eksopolisakaraida Sebagai Inokulan Area Pertanian Lahan Kering. BioTrends 7(1):35-41. BioTrends, 7(1), 35-41.

Rai, M. (2006). Handbook of Microbial Biofertilizer. Food Production Press, New York.

Sertua, H. J., Lubis, A., \& Marbun, P. (2014). Aplikasi Kompos Ganggang Cokelat ( Sargassum polycystum ) Diperkaya Pupuk. Jurnal Online Agroekoteknologi ., 2(4), 1538-1544.

Spaepen, S., Vanderleyden, J., \& Okon, Y. (2009). Chapter 7 Plant Growth-Promoting Actions of Rhizobacteria. In Advances in Botanical Research (1st ed., Vol. 51, Issue C). Elsevier Ltd. https://doi.org/10.1016/S0065-2296(09)51007-5

Sumarni, N., Sumiati, E., \& Suwandi, S. (2005). Pengaruh Kerapatan Tanaman Dan Aplikasi Zat Pengatur Tumbuh Terhadap Produksi Umbi Bibit Bawang Merah Asal Biji Kultivar Bima. Jurnal Hortikultura, 15(3), 83686. https://doi.org/10.21082/jhort.v15n3.2005.p

Suwandi, N., Sumarni, \& Sutiarso, T. A. (1995). Persebaran Produksi dan Konsumsi dalamTeknologi Produksi Bawang Merah. Pusat Penelitian Dan Pengembangan Hortikultuar, Badan Penelitian Dan Pengembangan Pertanian, Jakarta., 51-56.

Syam, A. (2003). Efektivitas Pupuk Organik dan Anorganik terhadap Produktivitas Padi di Lahan Sawah. Jurnal Agrivigor, 3(2), 232-244. 
Syamsiah, M., \& Royani. (2014). Respon Pertumbuhan Dan Produksi Tanaman Cabai Merah ( Capsicum annum L .) Terhadap Pemberian PGPR ( Plant Growth Promoting Rhizobakteri ) Dari Akar Bambu Dan Urine Kelinci. Agroscience, 4(2), 109-114. 
Tuhuteru, S., Sulistyaningsih, E., \& Wibowo, A. (2017). Effects of Plant Growth Promoting Rhizobacteria (PGPR) on Growth and Yield of Shallot in Sandy Coastal Land. Ilmu Pertanian (Agricultural Science), 1(3), 105. https://doi.org/10.22146/ipas.16349

Vessey, J. K. (2003). Plant growth promoting rhizobacteria as biofertilizers. Plant and Soil, 255(2), 571-586. https://doi.org/10.1023/A:1026037216893

Widarti, B. N., Wardhini, W. K., \& Sarwono, E. (2015). Pengaruh Rasio C/N Bahan Baku Pada Pembuatan Kompos Dari Kubis dan Kulit Pisang. Jurnal Integrasi Proses, 5(2), 75-80.

Widawati, S., Suliasih, \& Latupapua, H. J. D. (2003). The application of soil microbes from Wamena Botanical Garden as biofertilizer (compost plus) on purple eggplant (Solanum melongena L.). International Conference of Botanical Garden, $15^{\text {th }}-18^{\text {th }}$ Juli 2003.

Widowati, L. R., Widawati, S., \& Hartatik, W. (2005). Pengaruh Pupuk Organik,Serapan hara dan Produksi Sayuran Tanaman Organik. Balai Penelitian Sayur, Lembang.

Widyati, E. (2013). Dinamika Komunitas Mikroba Di Rizosfir Dan Kontribusinya Terhadappertumbuhan Tanaman Hutan. Tekno Hutan Tanaman, 6(2), 55-64.

Yuwono, D. (2005). Kompas. Penebar swadaya. Jakarta.

Zainudin, Abadi, A. L., \& Aini, L. Q. (2014). Pengaruh Pemberian Plant Growth Promoting Rhizobacteria (Bacillus subtilis dan Pseudomonas fluorescens)Terhadap Penyakit Bulai Pada Tanaman Jagung (Zea mays L.). Jurnal HPT, 2(1), 11-18. 